\title{
Identification of Various Micro-organisms Found in Sweetpotatoes and Guava
}

\author{
Lilybett Valentin-Ramos ${ }^{1}$
}

INTRODUCTION

The processing of tropical fruits and vegetables is being extensively investigated at the Food Technology Laboratory of the Agricultural Experiment Station of the University of Puerto Rico. Many of these fruits and vegetables can either be hot-packed in cans or frozen. Information is lacking on suitable processing schedules for most of these products. In order to develop proper processing schedules, as well as adequate assay procedures to determine the contamination of frozen products, a research project is being carried out in this Laboratory to identify the natural flora generally present in the fruits and vegetables grown in Puerto Rico. This paper deals with the isolation and identification of organisms present in sweetpotatoes and guavas.

\section{MATERIALS AND METHODS}

\section{SWEETPOTATOES AND GUAVAS}

Sweetpotatoes of the U.P.R. 3 and Rico varieties were used. All samples were obtained from the Isabela Substation and harvested at $4 \frac{1}{2}$ months after planting.

Fresh guavas, at different degrees of ripeness were obtained from various orchards through the eastern portion of the Island.

CULTURE MEDIA

Tryptone Glucose Extract Agar (Difco) and Nutrient Agar (Difco), respectively, were used for the isolation and storage of the micro-organisms obtained from guavas and sweetpotatoes. Special differential media were used for the characterization of the micro-organisms isolated.

\section{EQUIPMENT}

A Waring Blendor was used to disperse the guava and sweetpotato in sterile water.

Inoculated media were incubated at $27^{\circ}, 37^{\circ}$, and $55^{\circ} \mathrm{C}$.

\section{SAMPLE PREPARATION}

Guavas and sweetpotatoes were peeled under aseptic conditions and the cortex and flesh collected in separate sterile Petri dishes. The cortex was

1 Research Assistant in Bacteriology, Agricultural Experiment Station, University of Puerto Rico, Río Piedras, P. R. 
transferred to a sterile stainless steel Waring Blendor jar and dispersed in sterile water for 2-3 minutes. Two parts of sterile water was added per part of cortex.

Using this homogeneous suspension as the starting material, serial dilutions were prepared. Aliquots from the various dilutions were seeded in sterile Petri dishes to which warm Tryptone Glucose Extract Agar (Difco) was added. The medium was allowed to solidify and was incubated at $27^{\circ}, 37^{\circ}$, and $55^{\circ} \mathrm{C}$. for over 24 hours.

The same method described above was repeated with the flesh of both products. Guavas were studied at different degrees of ripeness.

TABLE 1.-Characteristics of individual cells of organisms isolated from sweetpotato

\begin{tabular}{|c|c|c|c|c|}
\hline \multirow{2}{*}{ Item } & \multicolumn{4}{|c|}{ Characteristics of organism- } \\
\hline & A & B & C & D \\
\hline Forms & Long, thin rods & Long rods & $\begin{array}{l}\text { Long rods, } \\
\text { may be en- } \\
\text { capsulated }\end{array}$ & $\begin{array}{l}\text { Long, thin } \\
\text { rods }\end{array}$ \\
\hline Size ${ }^{1}$ & & & & \\
\hline 1. & $1.75-2.25$ & $1.5-3.5$ & $1.5-3.5$ & $1.5-3.5$ \\
\hline w. & $0.5-0.75$ & $0.5-1$ & $0.45-0.75$ & $0.4-1$ \\
\hline Gram stain & + & + & + & + \\
\hline Acid-fast stain & - & - & - & - \\
\hline Movement & + & + & + & + \\
\hline Spores & $\begin{array}{l}\text { Ellipsoidal sub- } \\
\text { terminal }\end{array}$ & $\begin{array}{l}\text { Ellipsoidal sub- } \\
\text { terminal. Spo- } \\
\text { rangia may be } \\
\text { swollen }\end{array}$ & $\begin{array}{l}\text { Ellipsoidal } \\
\text { central }\end{array}$ & $\begin{array}{l}\text { Ellipsoidal } \\
\text { central to } \\
\text { para-cen- } \\
\text { tral }\end{array}$ \\
\hline
\end{tabular}

\footnotetext{
1 Size in microns.
}

All colonies of apparently different organisms were separated and purified after the period of incubation was over.

Morphological and physiological characteristics of each micro-organism were determined. Final classification of the different organisms was carried out in accordance with Bergey's Manual of Determinative Bacteriology.

\section{RESULTS AND DISCUSSION}

The results of the tests made for the classification of the bacteria isolated from sweetpotatoes are summarized on tables 1 to 4 . It was possible to isolate four apparently different organisms identified by letters A to D.

Studying the characters of the individual cells (table 1) it was found that the four organisms appeared as long, motile, sporogenous, Grampositive bacilli. Although the colonies belonging to the four organisms were similar in color and form (table 2) they varied in elevation, consistency, 
and margin. All the organisms except B produced a white pellicle when grown on Nutrient Broth (Difco). It was found that the optimum growth temperature was around $30^{\circ} \mathrm{C}$. These characteristics indicated that the organisms isolated from sweetpotatoes belonged to the Genus Bacillus.

Specific biochemical reactions were then studied to determine as closely as possible the species to which each of the four isolates belonged. The diameter of the vegetative rods (table 1); appearance of the protoplasm of young cells growing on glucose agar; growth on soybean agar (2) ${ }^{2}, 7$ percent $\mathrm{NaCl}$ broth $(3,4)$, tyrosine agar $(5)$; citrate utilization; casein and starch hydrolysis; production of catalase, acetyl-methyl-carbinol and lecithinase (6) (table 4); and the fermentation of carbohydrates-primarily

TABLE 2.-Morphology of the colonies of organisms isolated from sweetpolato

\begin{tabular}{|c|c|c|c|c|}
\hline \multirow{2}{*}{ Item } & \multicolumn{4}{|c|}{ Characteristics of organism- } \\
\hline & $\mathbf{A}$ & B & C & D \\
\hline Form & $\begin{array}{l}\text { Small, circular } \\
\text { irregular }\end{array}$ & Confluent & $\begin{array}{l}\text { Circular, conflu- } \\
\text { ent }\end{array}$ & $\begin{array}{l}\text { Circular, irregu- } \\
\text { lar, confluent }\end{array}$ \\
\hline Elevation & Raised & Raised & $\begin{array}{l}\text { Effuse or umbo- } \\
\text { nate }\end{array}$ & $\begin{array}{l}\text { Effuse or umbo- } \\
\text { nate }\end{array}$ \\
\hline Margin & Entire & Ramose & Entire or erose & Crenate or erose \\
\hline Consistency & Opaque, smooth & Smooth & Finely granular & $\begin{array}{l}\text { Coarsely granu- } \\
\text { lar }\end{array}$ \\
\hline Color & White & White & White & White \\
\hline $\begin{array}{c}\text { Growth on } \\
\text { Broth }\end{array}$ & White pellicle & $\begin{array}{l}\text { Faintly } \\
\text { diffused; } \\
\text { sedi- } \\
\text { ment }\end{array}$ & $\begin{array}{l}\text { White, rough } \\
\text { pellicle }\end{array}$ & $\begin{array}{l}\text { White, smooth } \\
\text { pellicle }\end{array}$ \\
\hline
\end{tabular}

glucose, lactose, sucrose, mannitol, arabinose, xylose, and glycerol-(table 3 ), were the main criteria used for differentiation into species.

Organisms A, C, and D have a diameter of less than $0.9 \mu$. They show a good, spreading growth on glucose agar with young cells staining uniformly. They grow well on soybean agar, 7-percent $\mathrm{NaCl}$ broth, tyrosine agar, citrate medium, and anaerobic glucose broth under anaerobic conditions. They have a positive reaction to hydrolysis of gelatin and casein and a negative reaction to starch hydrolysis. They produce catalase and acetyl-methylcarbinol, but give a negative lecithinase test. Organisms A, C, and D appear very similar to Bacillus licheniformis.

Organism B has a diameter of over $0.9 \mu$. It grows well on glucose agar, producing large, vacuolated cells. It produces catalase and acetyl-methylcarbinol. It has the ability to reduce nitrates and hydrolyze gelatin, casein,

2 Italic numbers in parentheses refer to Literature Cited pp. 289-90. 
and starch, and gives a positive lecithinase test. This organism does not produce acid from arabinose, xylose, or mannitol. It can be concluded that organism B is similar to Bacillus cereus.

TABLE 3.-Fermentation reactions of organisms isolated from sweetpotato

\begin{tabular}{|c|c|c|c|c|}
\hline \multirow{2}{*}{ Carbohydrate } & \multicolumn{4}{|c|}{ Characteristics of organism - } \\
\hline & A & B & C & D \\
\hline $\begin{array}{l}\text { Arabinose } \\
\text { Rhamnose } \\
\text { Xylose } \\
\text { Glucose } \\
\text { Fructose } \\
\text { Galactose } \\
\text { Mannose } \\
\text { Lactose } \\
\text { Sucrose } \\
\text { Maltose } \\
\text { Trehalose } \\
\text { Melibiose } \\
\text { Raffinose } \\
\text { Melezitose } \\
\text { Starch } \\
\text { Inulin } \\
\text { Dextrin } \\
\text { Glycogen } \\
\text { Glycerol } \\
\text { Erythritol } \\
\text { Adonitol } \\
\text { Mannitol } \\
\text { Sorbitol } \\
\text { Dulcitol } \\
\text { Salicin } \\
\text { Aesculin } \\
\text { Alpha-methyl glucoside }\end{array}$ & $\begin{array}{l}- \\
- \\
+ \\
+ \\
+ \\
+ \\
+ \\
\pm \\
- \\
\pm \\
- \\
- \\
- \\
- \\
- \\
- \\
\pm \\
- \\
+ \\
- \\
- \\
+ \\
+\end{array}$ & $\begin{array}{l}- \\
- \\
+ \\
+ \\
+ \\
\pm \\
\pm \\
- \\
+ \\
+ \\
- \\
- \\
+ \\
+ \\
+ \\
- \\
- \\
- \\
- \\
+\end{array}$ & $\begin{array}{l}- \\
- \\
+ \\
+ \\
- \\
- \\
+ \\
\pm \\
- \\
- \\
- \\
- \\
- \\
- \\
- \\
- \\
- \\
- \\
- \\
- \\
- \\
-\end{array}$ & $\begin{array}{l}- \\
- \\
- \\
+ \\
+ \\
\bar{t} \\
\overline{-} \\
\pm \\
\pm \\
- \\
- \\
- \\
- \\
- \\
\pm \\
- \\
- \\
\pm \\
- \\
- \\
\pm \\
\pm \\
- \\
\pm \\
\pm \\
-\end{array}$ \\
\hline
\end{tabular}

\section{SWEETPOTATOES}

GUAVAS

The results of tests carried out on guavas are summarized on tables 5 to 8. It was possible to isolate nine cultures, seven of which were motile, sporogenous Gram-positive or Gram-variable rods of varying sizes; and two Gram-positive cocci with cells arranged in irregular masses (table 5). The rods numbered from 1 to 7 can grow under aerobic or anaerobic conditions preferably at temperatures close to $30^{\circ} \mathrm{C}$. The cocci presented a more 


\begin{tabular}{|c|c|c|c|c|}
\hline \multirow{2}{*}{ Reaction } & \multicolumn{4}{|c|}{ Characteristics of organism- } \\
\hline & A & B & c & D \\
\hline $\begin{array}{l}\text { Gelatin hy- } \\
\text { drolysis }\end{array}$ & + & + & + & + \\
\hline $\begin{array}{l}\text { Indole produc- } \\
\text { tion }\end{array}$ & - & - & - & - \\
\hline $\begin{array}{l}\text { Nitrate reduc- } \\
\text { tion }\end{array}$ & + & + & + & + \\
\hline $\begin{array}{l}\text { Catalase pro- } \\
\text { duction }\end{array}$ & + & + & + & + \\
\hline $\begin{array}{l}\text { Decomposi- } \\
\text { tion of urea }\end{array}$ & - & - & - & - \\
\hline $\begin{array}{l}\text { Citrate utili- } \\
\text { zation }\end{array}$ & + & + & + & + \\
\hline $\begin{array}{l}\text { Casein hy- } \\
\text { drolysis }\end{array}$ & + & + & + & + \\
\hline$\underset{\text { tion }}{\mathrm{H}_{2} \mathrm{~S}}$ produc- & - & - & - & - \\
\hline $\begin{array}{l}\text { Litmus milk } \\
\text { reaction }\end{array}$ & $\begin{array}{l}\text { Peptonization, } \\
\text { slow reac- } \\
\text { tion }\end{array}$ & $\begin{array}{r}\text { Peptonization, } \\
\text { fast reaction }\end{array}$ & $\begin{array}{l}\text { Peptonization, } \\
\text { fast reaction }\end{array}$ & $\begin{array}{r}\text { Peptonization, } \\
\text { fast reaction }\end{array}$ \\
\hline $\begin{array}{l}\text { Methyl-red } \\
\text { test }\end{array}$ & \pm & + & - & - \\
\hline $\begin{array}{l}\text { Voges-Pro- } \\
\text { skauer test }\end{array}$ & + & + & + & + \\
\hline $\begin{array}{l}\text { Growth on } 7- \\
\text { percent } \\
\mathrm{NaCl} \text { broth }\end{array}$ & $\begin{array}{l}\text { Good; granular } \\
\text { pellicle }\end{array}$ & Good & Good; pellicle & Good \\
\hline $\begin{array}{l}\text { Growth on An- } \\
\text { aerobic Glu- } \\
\text { cose Broth }\end{array}$ & Good; pellicle & Good; diffused & do. & Good; pellicle \\
\hline $\begin{array}{l}\text { Growth on al- } \\
\text { kaline ana- } \\
\text { erobic ni- } \\
\text { trate agar }\end{array}$ & Good; $z+$ & Good; + & Good; z+ & Good; + \\
\hline $\begin{array}{l}\text { Growth on } \\
\text { Proteose } \\
\text { Peptone } \\
\text { Acid Agar }\end{array}$ & Fair & Very good & Very good & Do. \\
\hline $\begin{array}{l}\text { Growth on Ty- } \\
\text { rosine Agar }\end{array}$ & $\begin{array}{l}\text { Good; white } \\
\text { colonies }\end{array}$ & Good & $\begin{array}{c}\text { Very good; } \\
\text { white colo- } \\
\text { nies }\end{array}$ & $\begin{array}{l}\text { Very good; } \\
\text { white colo- } \\
\text { nies }\end{array}$ \\
\hline $\begin{array}{ll}\text { Growth } & \text { on } \\
\text { soybean } & \\
\text { agar } & \end{array}$ & Good & do. & $\begin{array}{l}\text { Good, flat, dry } \\
\text { growth }\end{array}$ & $\begin{array}{l}\text { Good, flat, dry } \\
\text { growth }\end{array}$ \\
\hline $\begin{array}{l}\text { Growth on Glu- } \\
\text { cose Agar }\end{array}$ & $\begin{array}{l}\text { Good; spread- } \\
\text { ing }\end{array}$ & do. & $\begin{array}{l}\text { Very good; } \\
\text { spreading }\end{array}$ & $\begin{array}{l}\text { Good; spread- } \\
\text { ing }\end{array}$ \\
\hline $\begin{array}{cc}\text { Gram-stain re- } \\
\text { action on } \\
\text { Glucose } & \text { Agar }\end{array}$ & $\begin{array}{l}\text { Small Gram }+ \\
\text { rods; stained } \\
\text { uniformly }\end{array}$ & $\begin{array}{l}\text { Large, vacuo- } \\
\text { lated } \\
\text { Gram } \\
\text { rods }\end{array}$ & $\begin{array}{l}\text { Small, encap- } \\
\text { sulated, } \\
\text { Gram varia- } \\
\text { ble rods }\end{array}$ & $\begin{array}{l}\text { Small, Gram + } \\
\text { rods, stain } \\
\text { uniformly }\end{array}$ \\
\hline $\begin{array}{l}\text { Lecithinase } \\
\text { test }\end{array}$ & - & + & - & - \\
\hline $\begin{array}{l}\text { Growth on po- } \\
\text { tato plugs }\end{array}$ & None & $\begin{array}{l}\text { Flat, moist, } \\
\text { off-white } \\
\text { color }\end{array}$ & $\begin{array}{l}\text { Dry, rough } \\
\text { wrinkled, } \\
\text { beige growth }\end{array}$ & $\begin{array}{l}\text { Dry wrinkled } \\
\text { cream-pink } \\
\text { color }\end{array}$ \\
\hline
\end{tabular}




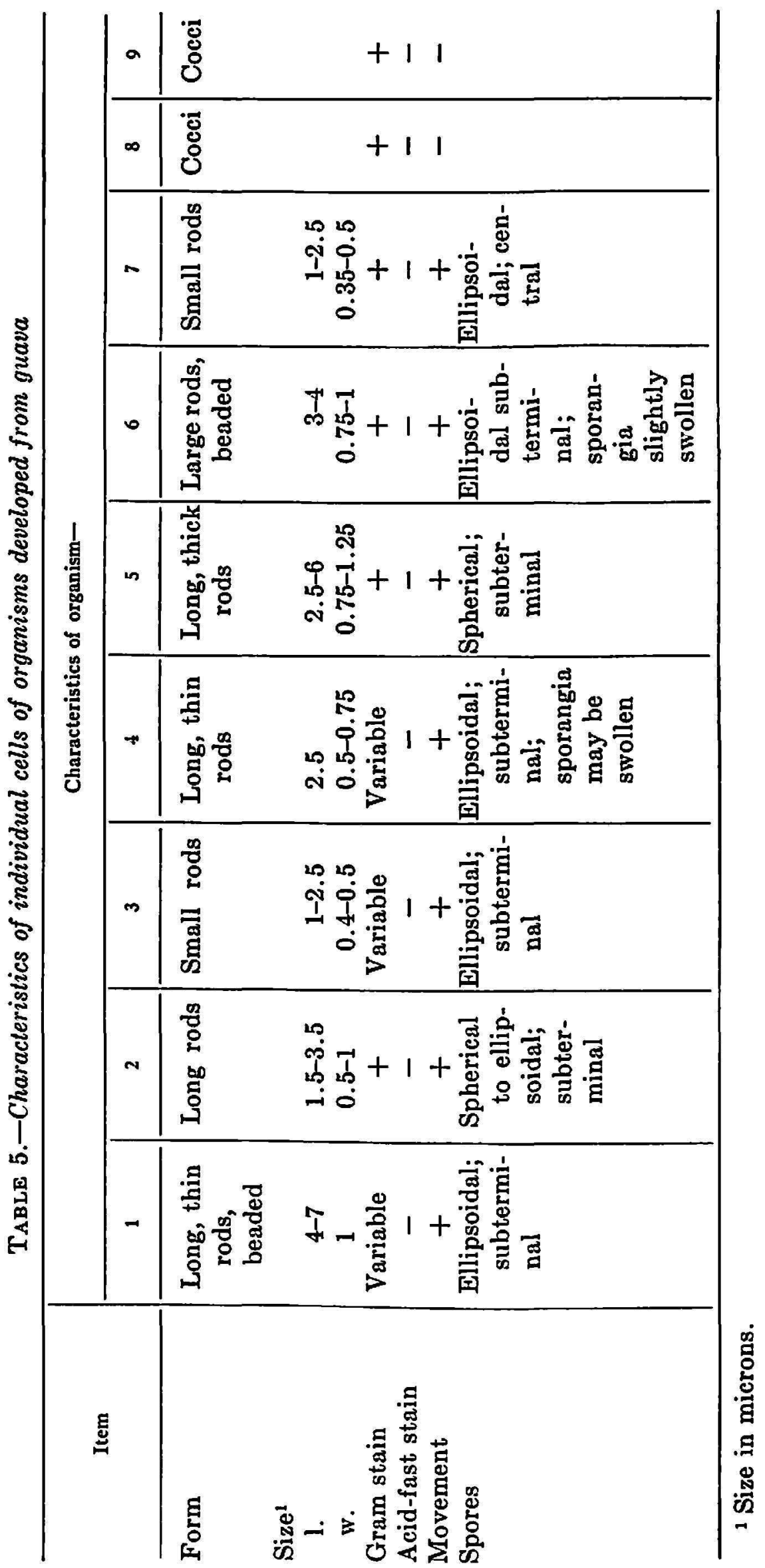


284 JOURNAL OF AGRICULTURE OF UNIVERSITY OF PUERTO RICO

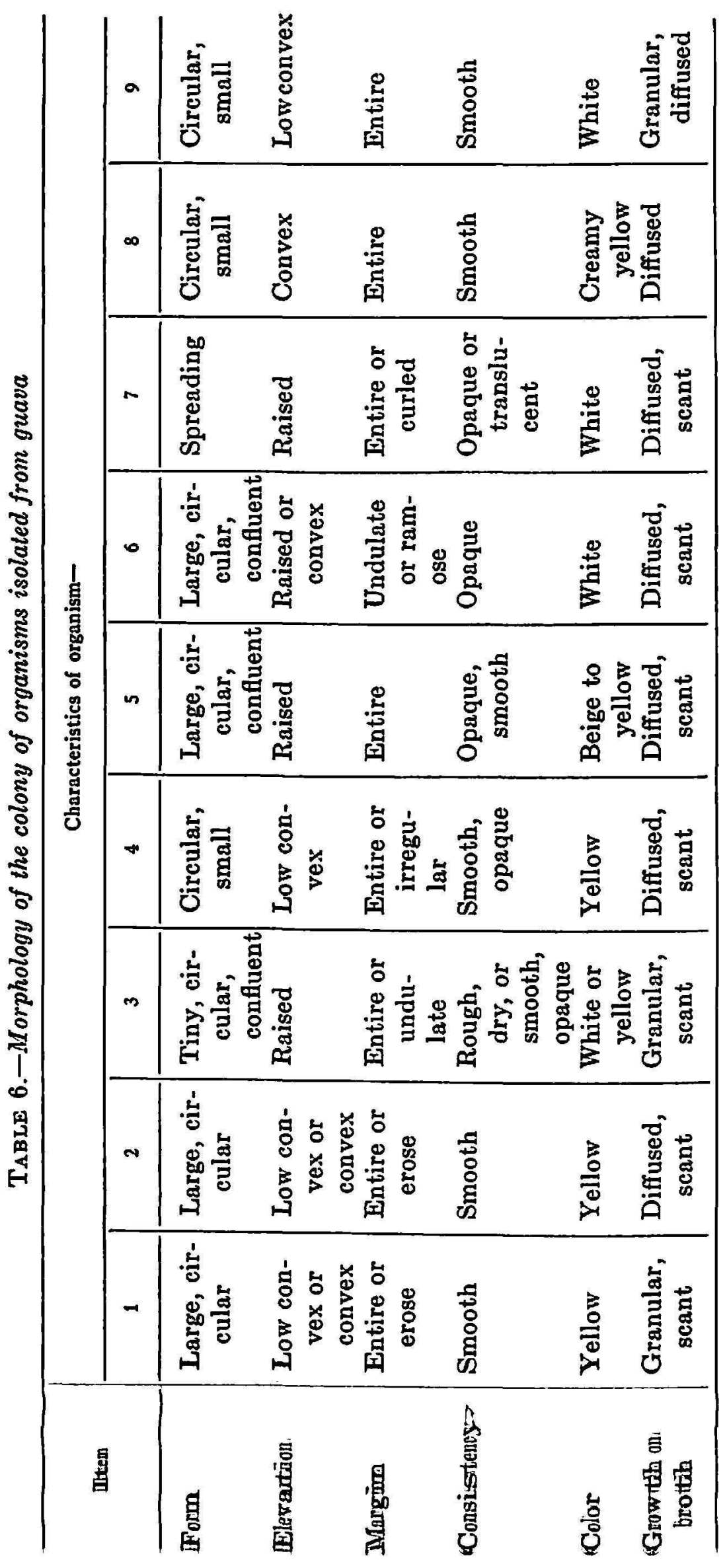


luxuriant growth at $37^{\circ} \mathrm{C}$. under aerobic conditions, although they developed under anaerobic conditions on glucose broth.

Observing the cellular morphology (table 5) and the characteristics of growth on solid and liquid media (table 6) it was evident that the rods

TABLE 7.-Fermentation reactions of organisms isolated from guava

\begin{tabular}{|c|c|c|c|c|c|c|c|c|c|}
\hline \multirow{2}{*}{ Carbohydrate } & \multicolumn{9}{|c|}{ Characteristics of organism- } \\
\hline & 1 & 2 & 3 & 4 & 5 & 6 & 7 & 8 & 9 \\
\hline Arabinose & \pm & + & - & - & \pm & \pm & - & \pm & \pm \\
\hline Rhamnose & - & - & - & - & - & - & - & - & - \\
\hline Xylose & \pm & \pm & - & - & \pm & - & - & \pm & \pm \\
\hline Glucose & + & + & + & + & + & + & + & $\stackrel{+}{+}$ & $\underset{\left(\mathrm{pH}^{5}\right.}{+}$ \\
\hline Fructose & \pm & + & + & \pm & + & + & + & + & + \\
\hline Galactose & + & + & - & \pm & \pm & \pm & + & \pm & + \\
\hline Mannose & + & \pm & \pm & - & \pm & - & + & + & + \\
\hline Lactose & + & + & - & \pm & + & \pm & - & + & + \\
\hline Sucrose & \pm & \pm & - & \pm & + & + & \pm & \pm & + \\
\hline Maltose & + & $\overline{+}$ & - & + & + & + & - & + & + \\
\hline Trehalose & - & \pm & - & - & \pm & + & \pm & \pm & - \\
\hline Melibiose & - & - & - & + & \pm & - & - & - & - \\
\hline Raffinose & + & + & - & - & + & - & - & - & - \\
\hline Melezitose & - & - & - & - & - & - & - & - & - \\
\hline Starch & \pm & \pm & - & \pm & + & - & - & - & \pm \\
\hline Inulin & - & \pm & - & - & - & - & - & - & \pm \\
\hline Dextrin & + & + & - & \pm & + & + & - & - & \pm \\
\hline Glycogen & - & + & - & + & + & - & - & - & + \\
\hline Glycerol & - & - & - & + & - & - & - & $\stackrel{+}{+}$ & $\stackrel{+}{+}$ \\
\hline Erythritol & - & - & - & - & - & - & - & - & - \\
\hline Adonitol & - & - & - & - & - & - & - & - & - \\
\hline Mannitol & \pm & - & - & - & \pm & - & \pm & + & - \\
\hline Sorbitol & + & - & - & - & - & - & - & - & - \\
\hline Dulcitol & - & - & - & - & - & - & - & - & - \\
\hline Salicin & - & - & + & - & - & - & t & - & - \\
\hline Aesculin & - & \pm & \pm & - & \pm & - & \pm & - & \pm \\
\hline Alpha-methyl glucoside & - & - & - & - & - & - & - & - & - \\
\hline
\end{tabular}

isolated from guavas belonged to the Genus Bacillus; and the cocci were members of the Family Micrococcaceae.

To differentiate the organisms into species a study of their biochemical reactions was carried out. Fermentation reactions on carbohydrates (table 7); hydrolysis of gelatin, casein, and starch; production of indole, hydrogen sulfide, catalase, and acetyl-methyl-carbinol; reaction on nitrates, citrate, 


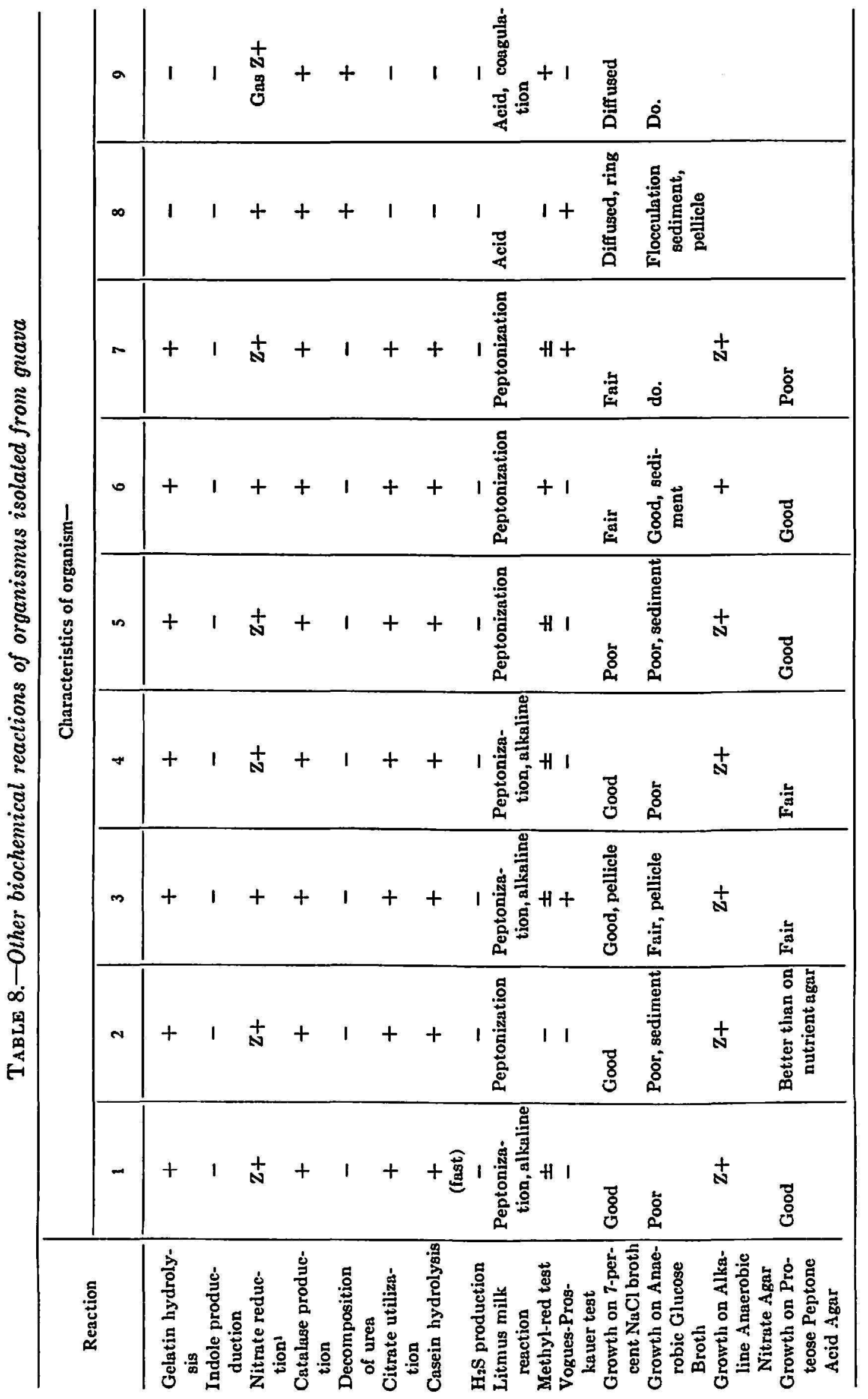




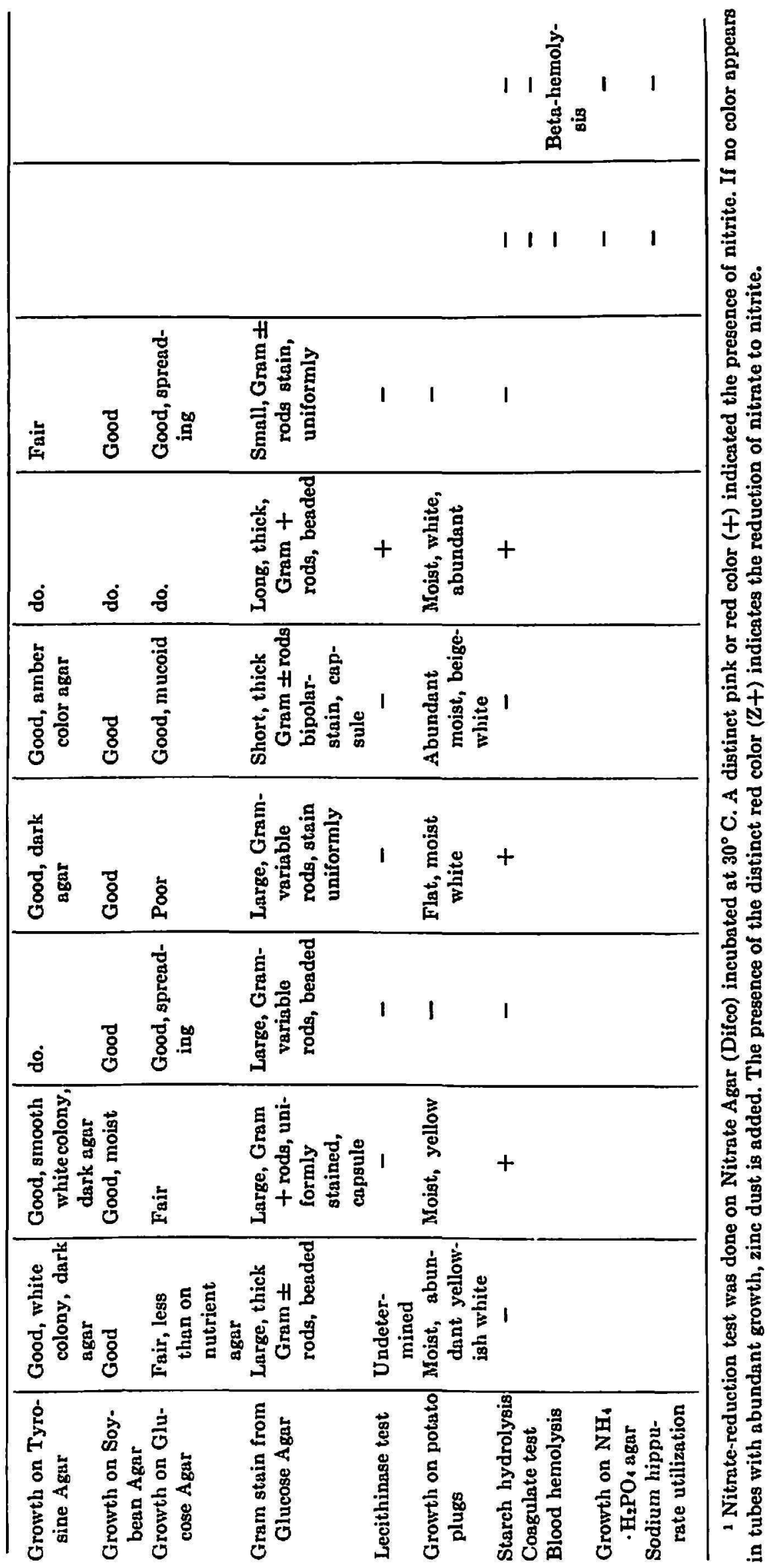


urea, and litmus milk; and growth on a salt-containing medium (table 8) were determined for each culture.

To characterize the species of the Genus Bacillus other tests besides the ones mentioned above were carried out. The ability to grow on such media as proteose peptone acid agar (Thermoacidurans Agar Difco), tyrosine agar, soybean agar, glucose agar, and anaerobic glucose broth (table 8) was determined.

Organisms 1 and 5 with a diameter of over $0.9 \mu$, with cells appearing vacuolated when grown on glucose agar, unable to produce acetyl-methylcarbinol, and lecithinase (table 8), and fermenting glucose, sucrose, and mannitol (table 7) appeared to be similar to Bacillus megatherium.

Organism 6 is also a large bacillus with a diameter of over $0.9 \mu$ and vacuolated protoplasm when grown on glucose agar. The facts that it did not ferment mannitol or xylose (table 7), and that it produced acetylmethyl-carbinol and lecithinase (table 8) indicated its similarity to Bacillus cereus.

Organisms $2,3,4$, and 7 are all smaller with a diameter of less than $0.9 \mu$ and all stain uniformly when grown on glucose agar. Organisms 3 and 7 vary in size from 1 to $2.5 \mu$ in length by 0.35 to $0.5 \mu$ in width. Both of them grow well on soybean agar and on 7-percent $\mathrm{NaCl}$ broth. They do not hydrolyze starch, do not produce acetyl-methyl-carbinol; but produce lecithinase. It can be said that organisms 3 and 7 are similar to Bacillus pumilus.

Organisms 2 and 4 grow well on soybean agar and 7-percent $\mathrm{NaCl}$ broth, but show poor development on anaerobic glucose broth. When grown on tyrosine agar they produce a pigment which turns the agar dark. These organisms are classified as Bacillus subtilis var. niger.

Organisms 8 and 9 appeared as nonmotile, Gram + spherical cells arranged in irregular masses. Both of them produce small, circular, smooth colonies with entire margin, creamy yellow to white in color (table 6). Both give an acid reaction in litmus milk and organism 9 caused coagulation also. Organism 8 showed no hydrolysis of starch, aesculin, and sodium hippurate (7). Both of them reduced nitrate, and give a positive reaction to production of catalase and decomposition of urea. Neither one utilized $\mathrm{NH}_{4} \mathrm{H}_{2} \mathrm{PO}_{4}$ $(8,9)$ as a source of nitrogen. Organism 9 shows beta-hemolysis on blood agar plates; not so organism 8 . The coagulase test for both of them was negative. Although various characteristics shown by organisms 8 and 9 appear to diverge from those expected of a Staphylococcus aureus; these organisms appear closer to this Genus than to any other of the Genera encountered in the Family Micrococcaceae.

All the organisms isolated from guavas and sweetpotatoes were encountered in the cortex. This is to be expected inasmuch as the isolates 
are organisms commonly found in nature whose habitat is the soil, dust particles, and plant surfaces.

\section{SUMMARY}

A study was undertaken for the purpose of obtaining information about the flora normally encountered in sweetpotatoes and fresh guavas.

Homogeneous suspensions of the cortex and flesh of both products were prepared in sterile water and used for the isolation of micro-organisms. Isolations were carried out on Tryptone Glucose Extract Agar plates incubated at $27^{\circ}, 37^{\circ}$, and $55^{\circ} \mathrm{C}$.

An extensive study of the morphological and physiological characteristics of each micro-organism was carried out in accordance with the 7th edition of the Bergey's Manual of Determinative Bacteriology (1957).

It was found that the organisms isolated from sweetpotatoes are similar to the Genera Bacillus cereus and B. lichemformis. Those isolated from guava were classified as Bacillus megatherium; B. cereus; B. pumilus; $B$. subtilis var. niger; and Staphylococcus aureus.

\section{RESUMEN}

El presente trabajo incluye los datos obtenidos de un estudio que se llevó a cabo para obtener información acerca de la flora que se encuentra normalmente en la guayaba y en la batata fresca.

Suspensiones homogéneas de la corteza y la pulpa de ambos productos fueron preparados en agua estéril, las cuales fueron usadas para aislar los microorganismos.

Se hizo un estudio abarcador de los caracteres morfológicos y fisiológicos de cada organismo para lo cual sirvió de guía la Séptima Edición del Manual de Bacteriología de Bergey (1957).

Se encontró que los organismos aislados de la batata son similares a los de los géneros Bacillus cereus y $B$. lichemformis. Los de la guayaba se clasificaron como Bacillus megatherium; B. cereus; B. pumilus; B. subtilis var. niger y Staphilococcus aureus.

\section{LITERATURE CITED}

1. Breed, R. S., Murray, E. G. D., Smith, N. R., Bergey's Manual of Determinative Bacteriology, 7th ed., Williams \& Wilkins Co., Baltimore, Md., 1957.

2. A Laboratory Manual for the Canning Industry 2nd. ed. National Canners Association, chap. 2-23, 1956.

3. Gordon, R. E., and Smith, N. R., Aerobic spore-forming bacteria capable of growth at high temperatures, J. Bact. 68 327-41, 1949.

4. Smith, N. R., Gordon, R. E., Clark, F. E., Aerobic Spore-Forming Bacteria, USDA Agricultural Monograph 16, 148 pp. 1952.

5. A Laboratory Manual for the Canning Industry, 2nd. ed. National Canners Association, chap. 2-24, 1956. 


\section{0}

JOURNAL OF AGRICULTURE OF UNIVERSITY OF PUERTO RICO

6. Colmer, A. R., The action of B. Cereus and related species on the lecithinase complex of egg yolk, J. Bact. 65 777-85, 1948.

7. Hajna, A. A., and Damon, S. R., Differentiation of A. aerogenes and A. cloacae on the basis of hydrolysis of sodium hippurate, Amer. J. Hyg., $1954508,1934$.

8. Hucker, G. J., Studies on the Coccaceae II, Study on the General Characters of the Micrococcaceae, N. Y. State Exp. Sta. Tech. Bul. 100, 83 pp. June 1924.

9. Hucker, G. J. Studies on the Coccaceae III, The Nitrogen Metabolism of the Micrococcaceae, N. Y. State Exp. Sta. Tech. Bul. 101, 47 pp., June 1924. 